\title{
ORIGINALS
}

\section{The Physiology and Pharmacology of Adipose Tissue Lipolysis: Its Inhibition and Implications for the Treatment of Diabetes*}

\author{
The Minkowski Award Lecture delivered on July 31, 1967 before the European Association for the Study \\ of Diabetes at Stockholm, Sweden
}

\author{
E. Rudolf Froesch
}

Metabolic Unit, Department of Medicine, University of Zurich, Switzerland

Received September 11, 1967

\begin{abstract}
Summary. The regulation of adipose tissue lipolysis occupies a key position in the metabolic concert of carbohydrates and lipids, and insulin plays the role of the conductor. Insulin favours the storage of fat in adipose tissue by 3 mechanisms: - 1. it inhibits lipolysis; 2 . increases the glucose uptake, lipogenesis and reësterjfication of free fatty acids; - 3. enhances the activity of lipoprotein-lipase, which is responsible for the uptake and storage of blood lipoproteins in adipose tissue. - On the other hand, basal lipolytic activity of adipose tissue is very much elevated in rats which are refed after prolonged starvation. It appears that insulin induces a lipase, which, in its presence, is nonfunctional. This dual role of insulin - induction of a lipase activity which it inhibits - would provide animals with a very efficient mechanism of switching from glucose utilization and lipid storage to lipid mobilization and oxidation. - High plasma levels of free fatty acids decrease glucose utilization of muscle and the effects of insulin thereon. Therefore, pharmacologic inhibition of lipolysis has been investigated in order to find now and better ways to adjust the metabolic situation in diabetes mellitus. We have used 5-methylpyrazole-3-carboxylic acid as a model antilipolytic compound. This drug, nicotinic acid and prostaglandin $\mathrm{E}_{1}$ not only inhibit lipolysis, but they also markedly enhance glucose uptake of adipose tissue in vivo. 5-methylpyrazole-3-carboxylic acid prevents the rise of the free fatty acids and of blood glucose acutely after the administration of anti-insulin serum. When this drug is administered over a period of several days, adipose tissue develops an escape mechanism; 5-methylpyrazole3 -carboxylic acid still effectively inhibits lipolysis and stimulates lipogenesis from glucose, but only for a short period of time. Basal lipolysis is activated and the newly synthesized glycerides are rapidly split and released as free fatty acids into the blood, so that soon after its administration the plasma level of free fatty acids is increased above normal. These findings shed doubt on the potential usefulness of antilipolytic drugs in the treatment of diabetes mellitus. - Purified nonsuppressible ILA of serum is mentioned as an antidiabetic substance of potential therapeutic interest since it increases glucose uptake of muscle more markedly than that of adipose tissue compared with insulin.
\end{abstract}

Physiologie et Pharmacologie de la lipolyse du tissu adipeux: son inhibition et ses implications dans le traitement du diabète.

Résumé. La régulation de la lipolyse occupe une position centrale dans le concert métabolique des glucides et lipides et l'insuline joue le rôle du chef d'orchestre. L'insuline augmente l'accumulation de graisse dans le tíssu

* The studies reported here were supported by the US Public Health Service (grant No. A $5^{\prime} 387$ ) and by the Schweizerische Nationalfonds (grant No. 3'854). adipeux par 3 méchanismes: - 1. elle inhibe la lipolyse, 2. stimule la captation de glucose, la lipogénèse et la réestérification des acides gras libres et - 3. rend active la lipoprotéine lipase qui est responsable de la captation des lipoprotéines du sang par le tissu adipeux. - D'autre part, la lipolyse des rats réalimentés après un jeûne prolongé est très active. Ceci signifie que l'insuline induit une lipase dont l'activité est inhibée par l'insuline même. Ce double rôle de l'insuline - induction d'une lipase qu'elle inhibe permet à l'animal d'une façon efficace et rapide de passer de l'utilisation de glucose et de la lipogénèse à la mobilisation d'acides gras libres pour les besoins énergétiques dès que le taux sanguin de l'insuline baisse. La musculature préfère les acides gras libres en forte concentration au glucose comme substrats d'oxydation et l'insuline perd de son efficacité. Les possibilités pharmacologiques d'inhiber la lipolyse afin de trouver des moyens pour mieux ajuster la situation métabolique du diabétique ont fait l'objet d'investigation. Dans ce but l'acide 5-methylpyrazole-3-carbonique fut utilisé. Cette substance ainsi que l'acide nicotinique et la prostaglandine $\mathrm{E}_{1} \mathbf{n}$ 'inhibent pas seulement la lipolyse mais ils augmentent aussi fortement la captation du glucose par le tissu adipeux in vivo. L'acide 5-methylpyrazole-3-carbonique ermpêche l'augmentation des acides gras libres ainsi que de la glycémie après injection de sérum anti-insulinique. Lorsque des animaux sont traités avec cette substance pendant plusieurs jours, la lipolyse spontanée basale est activée. L'acide 5-methylpyrazole-3-carbonique est encore capable d'inhiber la lipolyse, mais la durée de son effet antilipolytique est diminuée. Les glycérides récemment synthétisés à partir du glucose sont rapidement hydrolysés et ils réapparaissent sous forme d'acides gras libres dans le sang. Le taux de ces derniers est alors augmenté bien au dessus de celui des contrôles. Ces résultats ne sont pas favorables à l'idée que des substances antilipolytiques pourraient se prouver utiles dans le traitement des diabétiques. - L'activité insulinique non supprimable extraite du sérum et purifiée mérite de l'intérêt du point de vue thérapeutique puisque, comparée à l'insuline, elle agit plus fortement sur la captation de glucose du muscle que du tissu adipeux.

Physiologie und Pharmakologie der Lipolyse des F'ettgewebes: Ihre Hemmung und Bedeutung bei der Behandlung des Diabetes mellitus.

Zusammenfassung. Die Regulation der Lipolyse des Fettgewebes nimmt im Stoffwechsel der Kohlehydrate und Fette eine zentrale Stellung ein, in der das Insulin die Rolle des Dirigenten spielt. Insulin fördert die Speicherung von Fett im Fettgewebe durch 3 Mechanismen. 1. Es hemmt die Lipolyse, - 2. fördert die Glucoseaufnahme, Lipogenese und Wiederveresterung der freien Fettsäuren und - 3. steigert die Aktivität der Lipoproteinlipase, welche die Aufnahme der Lipoproteine des 
Blutes in das Fettgewebe bewerkstelligt. - Anderseits ist die spontane, basale Lipolyse des Fettgewebes von Ratten, die nach längerem Fasten wiedergefüttert wurden, außerordentlich aktiv. Insulin schoint eine Lipase im Fettgewebe zu induzieren, deren Aktivität in Anwesenheit von Insulin gehemmt ist. Diese zweifache Rolle des Insulins - Induktion einer Lipase, die es selbst hemmt - stattet das Tier mit einor wirkungsvollen Regulationsmöglichkeit des Intermediärstoffwechsels aus, indem es durch Ein- und Abschalten der Insulinsekretion von der Glucoseverbrennung und Fettspeicherung auf die Mobilisierung der Fettreserven und die Verbrennung freier Fettsäuren übergehen kann. - Die Muskulatur zieht freie Fettsäuren in hoher Konzentration der Glucose als Substrat vor und Insulin verliert an Wirksamkeit. Die pharmakologischen Möglichkeiten der Hemmung der Lipolyse wurden untersucht, in der Hoffnung, neue Wege für eine Verbesserung der Stoffwechselsituation des Diabetikers zu finden. 5-Methylpyrazol-3-carbonsäure wurde als sehr wirksame antilipolytische Substanz verwendet. Es zeigte sich, daß diese Substanz, Nicotinsäure und Prostaglandin $\mathrm{E}_{1}$ nicht nur die Lipolyse hemmen, sondern auch die Glucoseaufnahme des Fettge- webes in vivo sehr stark steigern. 5-Methylpyrazol-3carbonsäuro verhindert den Anstieg der freien Fettsäuren und des Blutzuckers kurz nach der Injektion von Anti-Insulinserum. Wird diese Substanz während mehrerer Tage verabreicht, so nimmt die spontane Lipolyse des Fottgewebes zu. Die Droge hernmt die Lipolyse und fördert die Glucoseaufnahme zwar immer noch, aber die Wirkungsdauer nimmt ab. Die neu synthetisierten Glyceride werden rasch wieder hydrolysiert und als freie Fett. säuren in das Blut abgegeben, so daß der Spiegel der freien Fettsäuren höher ansteigt als bei Kontrolltieren. Diese Daten lassen daran zweifeln, daß diese antilipolytischen Substanzen in der Therapie des Diabetes mellitus einen Platz finden werden. - Die gereinigte und nicht hemmbare Insulinaktivität des Serums scheint hingegen in dieser Beziehung recht vielversprechend, weil sie, ver glichen mit Insulin, die Glucoseaufnahme der Muskulatur mehr steigert als die des Fettgewebes.

Key-words: Diabetes, adipose tissue, lipolysis, anti-lipolysis, insulin, non-suppressible ILA, glucose metabolism, fructose metabolism, 5-methylpyrazole-3-carboxylic acid, nicotinic acid, prostaglandin, fasting-refeeding

\section{Introduction}

On the occasion of the first lecture held in honour of MrNkowski a year ago, Dr. RaNdLe [29] stated that an essential feature of his concept of the glucose fatty acid cycle was the idea that deficiencies in the uptake and metabolism of glucose were not primarily responsible for the augmented release and oxidation of fatty acids in diabetes. HALES and RANDLE [20] suggested that one of the very early aberrations of metabolism in diabetes might be an elevation of the level of free fatty acids diminishing the sensitivity of tissues to insulin and finally leading to glucose intolerance by way of an exhaustion of the $\beta$-islet cells. There is good evidence that free fatty acids may be oxidized in muscle in preference to glucose, and that the level of free fatty acids is one of the factors that regulate overall glucose utilization [11, 27, 38, 30]. If diabetes did begin with a high level of free fatty acids, ways should be found to bring their level back to normal. Since adipose tissue is the only source of free fatty acids, it was reasonable to search for antilipolytic drugs which - by way of lowering the free fatty acid concentration in plasma would be expected to increase the glucose uptake and metabolism of muscle and the efficacy of insulin thereon. Acutely, this goal may be achieved. However, long term therapy with antilipolytic drugs has not been successful owing to the very ingenious ability of Nature; in this instance, adipose tissue not allowing itself to be fooled by the pharmacologist. Before we tackle this problem, I shall quickly review some aspects of lipolysis and of its regulation.

Regulation of lipolysis by the availability of glucose, i.e. by reësterification of free fatty acids with $\alpha$-glycerophos-

$$
\text { phate }
$$

Fig. 1 shows schematically the main reactions involved in the regulation of the release of glycerol and free fatty acids by adipose tissue. Free fatty acid

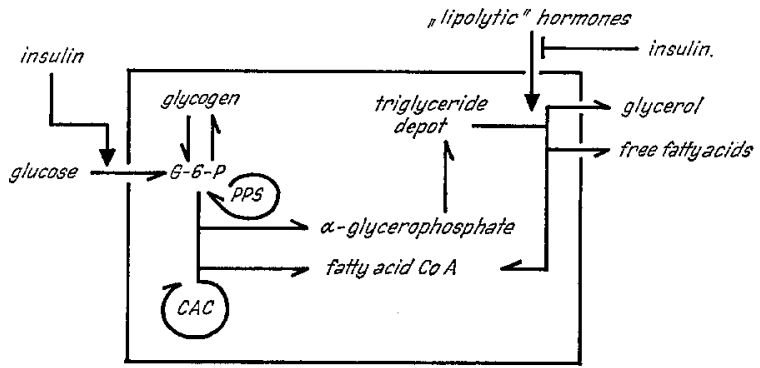

Fig. 1: Reactions involved in the regulation of the release of free fatty acids and glycerol by adipose tissue

release depends not only on the activity of the lipase, but also on the availability of glucose for their reësterifieation with $\alpha$-glycero-phosphate (for a detailed review see VAUGHAN and STEINBERg [37]).

We know from studies with adipose tissue in vitro, that the free fatty acid release decreases as the glucose concentration in the medium is increased. This observation is physiologically not very meaningful since glucose transport in adipose tissue in vitro does not follow the same rules as glucose transport in vivo. Glucose uptake of adipose tissue in vivo ceases almost completely when anti-insulin serum is administered or when insulin secretion is stopped by the administration of mannoheptulose [18]. Thus, reësterification of free fatty acids in vivo primarily depends upon the action of insulin on glucose transport and not on the glucose concentration. Without insulin glucose does not pass the barrier of the cell membrane and it remains unavailable for cellular metabolism.

I know only of one example of a fall of free fatty acids by increased reësterification in vivo concomittant with a decreasing plasma insulin level. Patients with hereditary fructose intolerance are unable to metabolize fructose in the liver owing to a deficiency of hepatic aldolase (for a review see Fromscr [12]). Fructose is phosphorylated; and fructose-1-phosphate accumu- 
lates and blocks glucose release from the liver so that hypoglycaemia develops. Fig. 2 shows that the level of free fatty acids falls in a patient with hereditary fructose intolerance in spite of hypoglycaemia and of a decreasing insulin concentration at a time when the fructose concentration in blood is high.

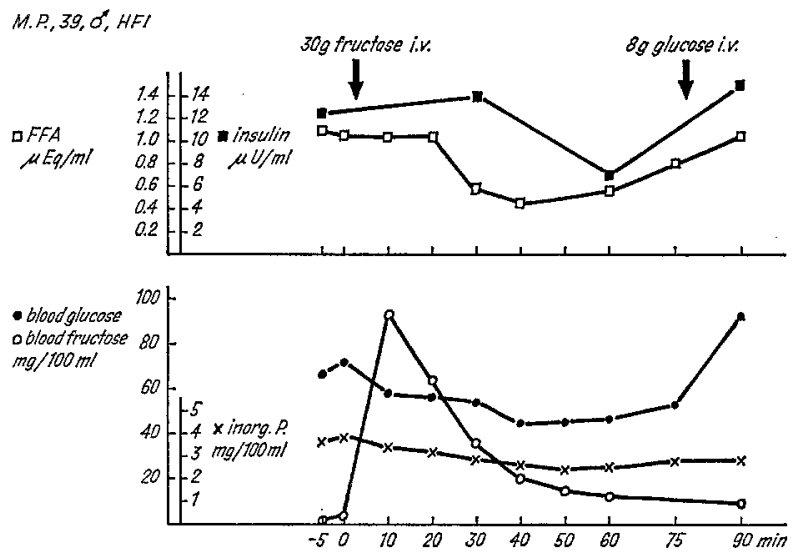

Fig. 2. Blood glucose and fructose, immunoreactive insulin and plasma free fatty acids in a patient with horeditary fructose intolerance during an intravenous tolerance test with $0.25 \mathrm{~g}$ fructose $/ \mathrm{kg}$

Only when hypoglycaemia becomes severe, does adrenergic counterregulation induce the plasma level of free fatty acids to rise again. The fall of free fatty acids, despite hypoglycaemia and low insulin levels, is due to the property of adipose tissue to take up glucose and fructose by separate transport systems, so that their metabolism is additive rather than competitive as in most other tissues [15]. In the presence of glucose and fructose, total hexose uptake is considerably greater than with glucose alone, and although hypoglycaemia develops, the level of free fatty acids falls as a result of increased reësterification. However, this is a very exceptional example of increased reësterification regulating the free fatty acid concentration at a time when insulinaemia is low.

Some time ago, BaLLy et al. [1] showed that glucose alone, or added together with insulin, may, under certain conditions, increase rather than decrease the rate of lipolysis in vitro. This occurs when at high rates of lipolysis free fatty acids accumulate in the adipose tissue cell and inhibit lipolysis. Addition of glucose alone or together with insulin may then relieve this inhibition by the formation of glycerides from free fatty acids through the supply of $\alpha$-glycero-phosphate. This observation may be an artefact of the incubation in vitro in which the outflow of free fatty acids into the medium is slow.

\section{The role of insulin in the regulation of lipolysis}

Insulin inhibits hormonally-induced lipolysis in vitro. Small concentrations of ACTH and of epinephrine are effectively counteracted by insulin [23, 21]. Growth hormone, with and without added glucocorticoids, stimulates lipolysis of adipose tissue and insulin inhibits its effect [10]. Spontaneous, basal lipolysis is also inhibited by insulin $[13,24,36]$.

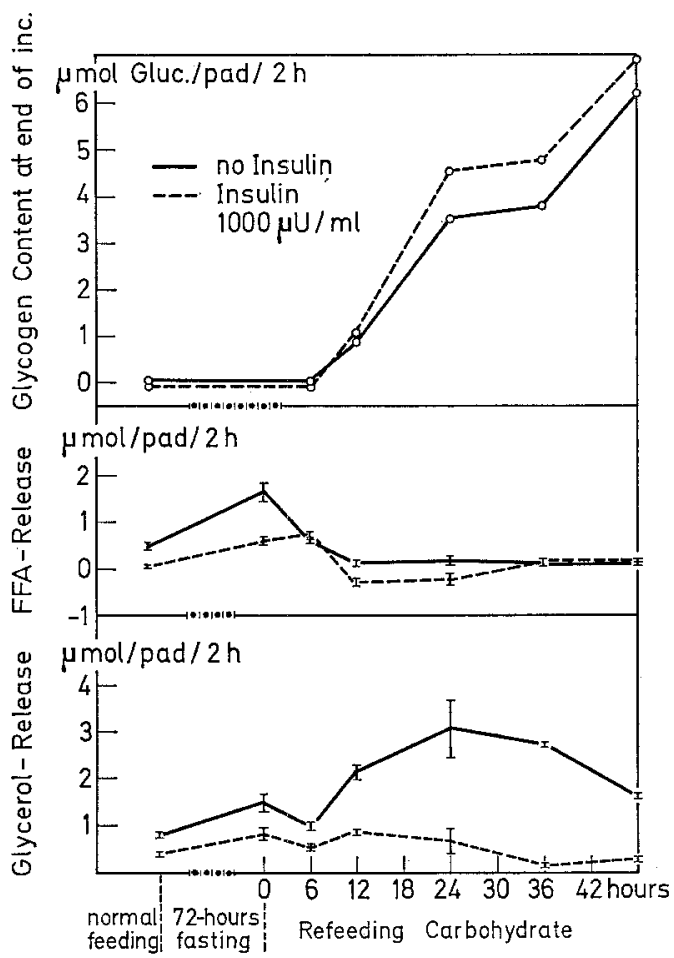

Fig. 3. Glycerol and free fatty acid release and glycogen content of adipose tissue of fasted - refed rats with and without insulin stimulation as a function of the duration of refeeding

Two groups of animals with a fasting period of 72 and $120 \mathrm{~h}$, respectively, were used. The tissue of 4 animals was pooled into 4 flasks, two of which contained insulin. The Krebs-Ringer bicarbonate buffer contained $4 \mathrm{~g}$ albumin per $100 \mathrm{ml}$ and no glucose. The incubation lasted $2 \mathrm{~h}$. The means of the results of two flasks and their range are plotted. (From FroEsch et al. [13])

This is illustrated in Fig. 3. Glycerol, free fatty acid release as well as glycogen content of adipose tissue were studied in fed, fasted and fasted-refed rats. Adipose tissue of fasted rats releases significantly greater amounts of glycerol into the medium than adipose tissue of fed rats. Insulin exerts a slight inhibitory effect. During the refeeding period, basal glycerol release increases to a level way above that found during fasting, and inhibition by insulin becomes very pronounced. Free fatty acid release does not parallel glycerol release during refeeding. As is shown in the top curve, glycogen accumulates in large amounts in the tissue during the refeeding period, providing $\alpha$-glycero-phosphate for the reësterification of the free fatty acids and making glucose superfluous for this purpose.

Lipolysis of adipose tissue of fasted-refed rats and its inhibition by insulin is, indeed, independent of the presence of glucose or any other substrate in the 
medium. Fig. 4 demonstrates that the formation of a-glycero-phosphate from exogenous glucose is unimportant for the release of free fatty acids in vitro since glycogen provides ample amounts of this substrate. Free fatty acids may actually be taken up by the tissue from the albumin-containing medium at a time when the glycerol release is very high [13].

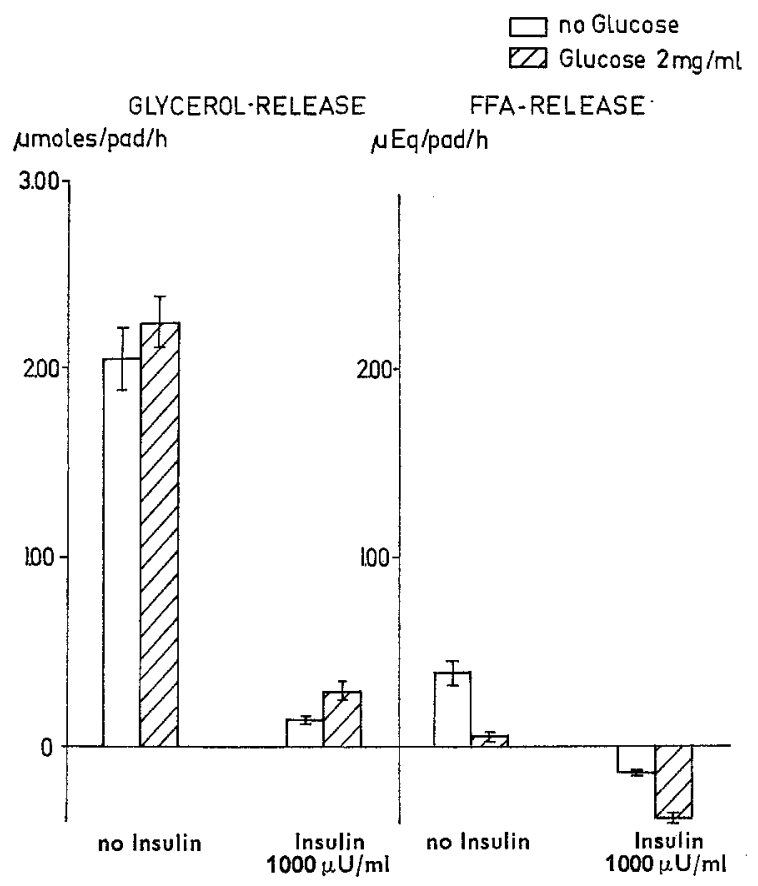

Fig. 4. Effect of insulin on release of glycerol and free fatty acids by adipose tissue of $72 \mathrm{~h}$ fasted $-24 \mathrm{~h}$ refed rats in the absence and presence of glucose

A pool of adipose tissue from 8 rats was used. The KrebsRinger bicarbonate medium contained $4 \mathrm{~g}$ albumin per $100 \mathrm{ml}$ and the incubation lasted for $3 \mathrm{~h}$. The bars represent the mean of the results of two flasks, and the range is given. (From Frowson et al. [13])

Thus, insulin seems to play a complex role in the regulation of lipolysis. As is demonstrated in Figs. 3 and 4 , insulin inhibits lipolysis of adipose tissue in vitro most markedly when rats were refed after fasting, i.e. when extremely high rates of glucose assimilation were maintained over a prolonged period of time by an elevated insulin level in blood. On the other hand, these high rates of glucose assimilation and of lipogenesis lead to a stimulation of basal lipase activity, which is inhibited or "non-functional" in the presence of insulin. As we shall see later, antilipolytic substances other than insulin also enhance lipogenesis in vivo and at the same time increase the basal lipase activity. Adrenergic mechanisms do not appear to be responsible for this activation of basal lipolysis by insulin for the following two reasons: 1. lipolysis of fasted-refed rats is not subject to suppression by propranolol, a blocker of the beta-receptors of adipose tissue cells; and 2 . treatment of rats with large doses of propranolol or 5-methylpyrazole-3-carboxylic acid during the refeeding period does not alter the lipolytic response of the tissue. Table 1 shows that propranolol in concentrations from $10^{-8}$ to $10^{-4} \mathrm{M}$ at which it blocks the response of adipose tissue to adrenaline and other lipolytic

Table 1. Independence of adipose tissue lipolysis of fastedrefed rats of the blocking of $\beta$-receptors by propranolol in vitro

The figures give the mean of the results of two flasks and their range

\begin{tabular}{llll}
\hline \multirow{4}{*}{ control } & propranolol concentration in vitro & \\
\hline $10^{-4} \mathrm{MI}$ & $10^{-6} \mathrm{M}$ & $10^{-8} \mathrm{M}$ \\
\hline glycerol release in $\mu \mathrm{moles} / \mathrm{g} / \mathrm{h}$ & & \\
\hline $14.0 \pm 0.4$ & $15.5 \pm 0.9$ & $15.9 \pm 0.9$ & $15.2 \pm 0.6$
\end{tabular}

hormones, does not change the spontaneous glycerol release of adipose tissue in vitro of fasted-refed rats. In another series of experiments rats were treated with propranolol or 5-methylpyrazole-3-carboxylic acid during the refeeding period. The latter drug inhibits lipolysis activated by $\alpha$ - and $\beta$-receptors of adipose tissue. Basal glycerol release of adipose tissue in vitro was not inhibited by these premedications (Table 2).

Table 2. Independence of adipose tissue lipolysis of fastedrefed rats of the administration of propranolol and 5-methylpyrazole-3-carboxylic acid during the 24 h-refeeding period Rats were fasted for $120 \mathrm{~h}$ and then refed for $24 \mathrm{~h}$. During the $24 \mathrm{~h}$ of refeeding they were treated with the $\beta$-receptor blocking agent propranolol or with 5-methylpyrazole-3carboxylic acid. Adipose tissue was pooled into 10 flasks and was incubated in. Krebs Ringer bicarbonate buffer containing no glucose and additions as indicated. The SEM (controls, $n=6$ ) or the range $(n=2)$ is given

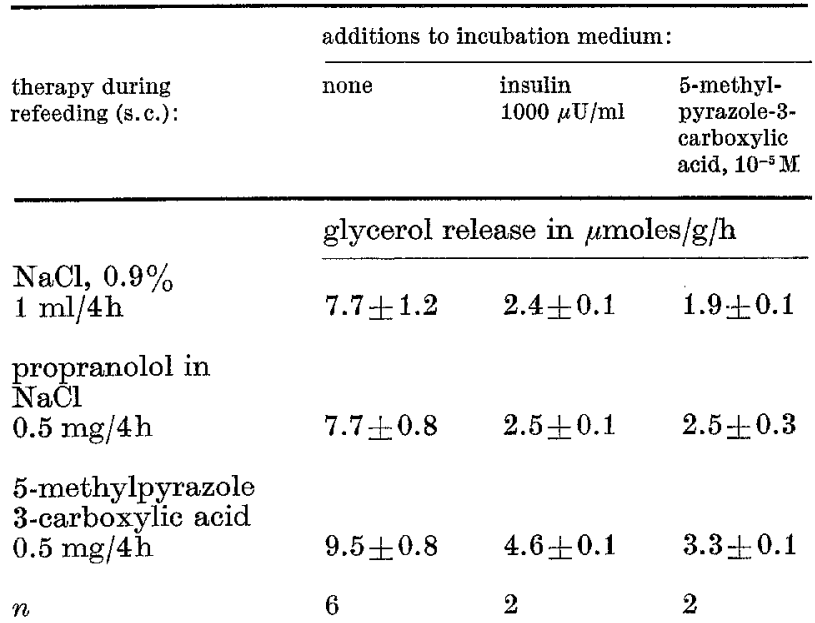

Thus, the role of insulin in the regulation of lipolysis appears to be twofold:

1. Insulin favours lipid storage in adipose tissue by 3 mechanisms:

a) by inhibiting lipolysis;

b) by increasing glucose uptake, lipogenesis and reësterification; 
c) by stimulating lipoprotein-lipase activity, which is responsible for the uptake of lipoproteins from blood (reviewed by RoBINson [31]).

2. On the other hand, insulin induces a lipase for the mobilization of stored lipids, which becomes active as soon as insulin release stops.

Teleologically this makes sense and would provide animals with feeding habits such as the lion, who eats enormous amounts at one time (equivalent of refeeding), and then rests until hunger overcomes his strong inclination towards peaceful laziness, with a very efficient regulation of energy metabolism. As long as hyperglycaemia lasts after feeding, insulin fills the energy stores by triglyceride synthesis and by inhibiting lipolysis. Lipolysis takes off again as soon as the blood glucose level falls off so that insulin release stops. The habit of fasting and refeeding probably was also characteristic for men - and still is in large parts of the world - before civilization made a more or less continuous food supply available to him, resulting in obesity, diabetes, atherosclerosis and - last but not least - dental caries.

The data in Fig. 5 show that the inhibition in vitro of lipolysis of adipose tissue of fasted-refed rats by

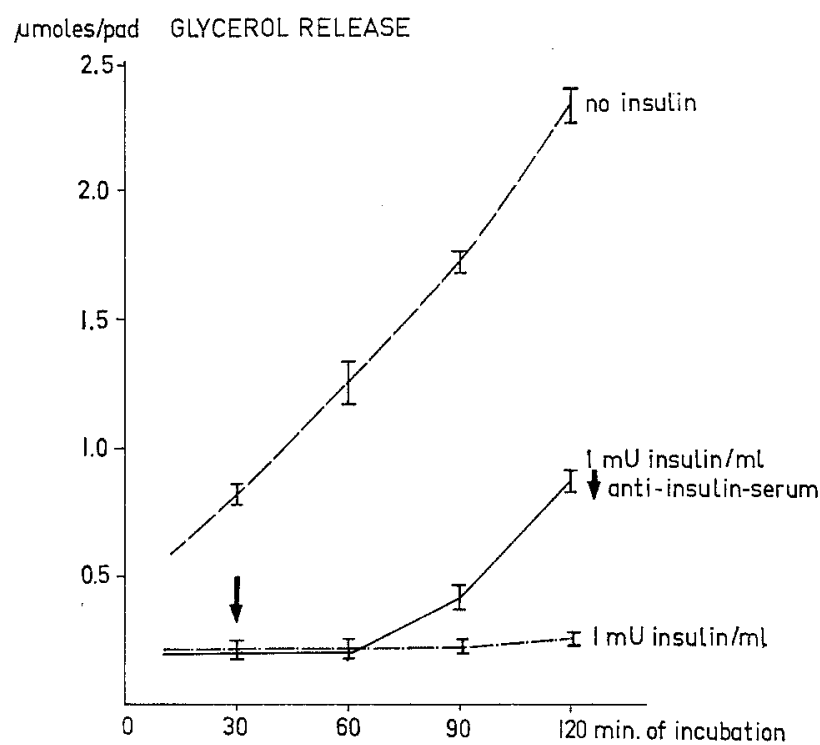

Fig. 5. Effect of anti-insulin serum on insulin-induced depression of glycerol release by adipose tissue of $120 \mathrm{~h}$ fasted $-24 \mathrm{~h}$ refed rats

A pool of epididymal adipose tissue of 16 rats was used. Each flask contained $2 \mathrm{ml}$ Krebs-Ringer bicarbonate buffer with $3 \mathrm{~g}$ albumin per $100 \mathrm{ml}$ and no glucose. Anti-insulin serum, $0.1 \mathrm{ml}$ with an insulin-neutralizing capacity of $50 \mathrm{mU}$, was added from the side arm of the Warburg vessel 30 min after the start of the incubation, as indicated by the arrow. To the control flasks $0.1 \mathrm{ml}$ normal guinea pig serum was added at the same time. The brackets indicate the results of the two flasks. (From Frowscr et al. [13])

insulin in the absence of glucose is readily reversible when anti-insulin serum is added to the incubation medium. During the two hours of incubation virtually no glycerol is released by the tissue that is under the influence of insulin. At $30 \mathrm{~min}$ after the addition of anti-insulin serum the tissue starts again to release glycerol at a similar, although not quite equal rate as nonstimulated tissue. A dose-response relationship between the insulin concentration and the inhibition of glycerol release is shown in figure 6 . Glycerol release by adipose tissue of fasted-refed rats is significantly inhibited at an insulin concentration of $31 \mu \mathrm{U}$ per ml.

GLYCEROL RELEASE IN \% OF BASELINE

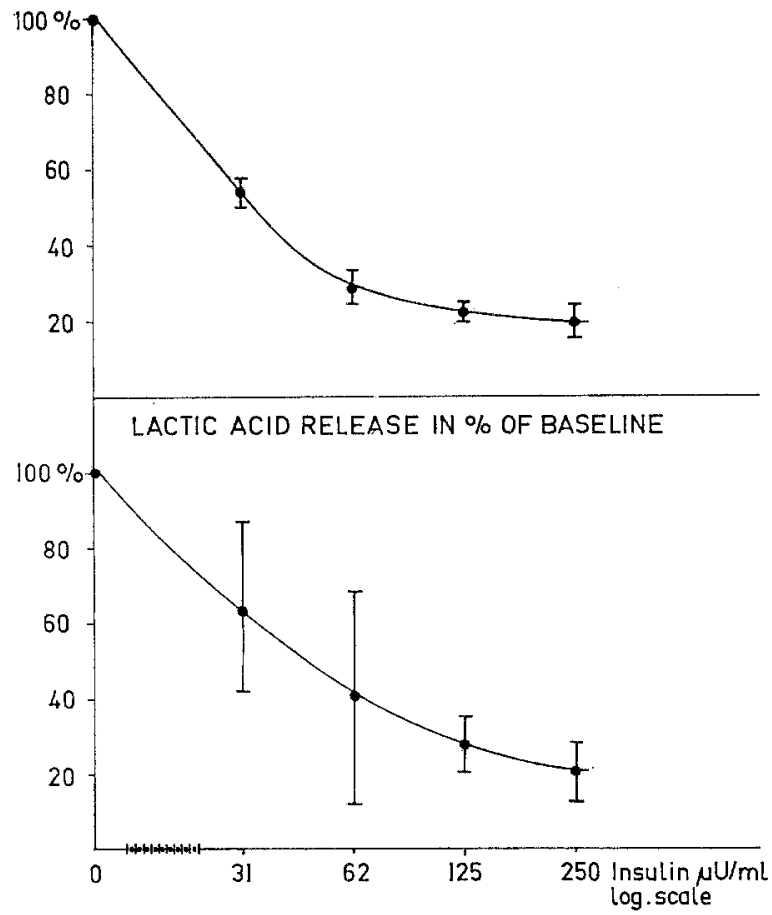

Fig. 6. Effect of insulin on release of glycerol and lactic acid by adipose tissue of fasted - refed rats in the absence of glucose

Two pools of epididymal adipose tissue each from 12 rats were used. One group of animals was fasted for $72 \mathrm{~h}$, the other for $144 \mathrm{~h}$, and all animals were refed for $24 \mathrm{~h}$. The Krebs-Ringer bicarbonate buffer contained $200 \mathrm{mg}$ gelatin per $100 \mathrm{ml}$ and no glucose. The results are expressed as the percentage of the value in the absence of insulin. The means of the results of 4 flasks and the SEM are given. (From FroEscr et al. [13])

The insulin effect becomes nearly maximal at a concentration of $250 \mu \mathrm{U}$ per $\mathrm{ml}$. The shape of the curve is independent of whether glucose is present in the medium or not. The output of lactic acid is also suppressed by insulin in the absence of glucose in the medium.

\section{Pharmacologic inhibition of lipolysis}

Ever since the first observations on the interrelation of the metabolism of free fatty acids and glucose were reported, and in particular since the hypothesis was put forward that diabetes mellitus might actually start off with an elevation of the free fatty acid level before an abnormality of glucose metabolism is 
discernible [20], a great deal of work has been carried out with drugs with antilipolytic activity.

Various potent drugs which inhibit spontaneous and hormonally-activated lipolysis are listed in Table 3. Of

Table 3. Substances inhibiting spontaneous lipolysis of adipose tissue of fasted - refed rats

The studies with nucleosides, nucleotides, nicotinic acid, 3-pyridil-acetic acid and phospholipases have not yet been published. Glycerol release of pooled epididymal adipose tissue of $120 \mathrm{~h}$ fasted $-24 \mathrm{~h}$ refed rats in the absence of glucose was used as a test system

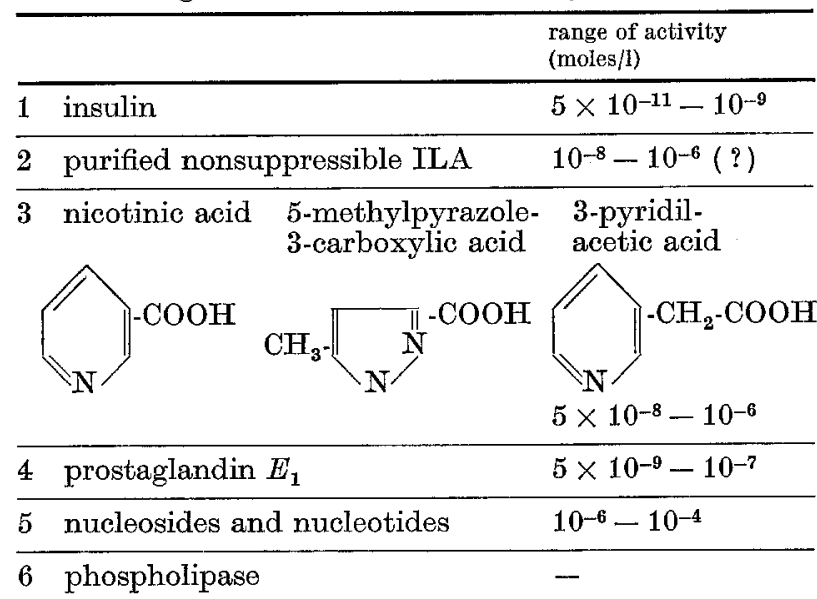

these, insulin is by far the most potent. It inhibits glycerol release of adipose tissue of fasted-refed rats at concentrations as low as $10^{-10} \mathrm{M}$. Purified nonsuppressible ILA of serum shows exactly the same curve of dose-response relationship, but its activity is about two potencies less than that of insulin [16]. The phospho-lipases are of interest since they inhibit lipolysis and, at the same time, increase glucose uptake of adipose tissue in vitro almost as much as insulin [32,2]. Under 3, drugs of similar structure are listed, i.e. nicotinic acid, 5-methylpyrazole-3-carboxylic acid and 3-pyridil-acetic acid. The antilipolytic properties of nicotinic acid have been investigated by CARLSON, OHSTMAN and BALLY among others (for review see CARLSON and BALLY [7]). 5-methylpyrazole-3-carboxylic acid is an interesting compound, which has a much longer biological half life than nicotinic acid [34]. Its antilipolytic and antidiabetic effects were first observed by SmitII, Forist, DULIN [33] and GerRITsex and DULIN [19] of the Upjohn Company. These 3 drugs have a similar ring structure and have in common a carboxyl group at a relatively constant distance from the nitrogen in the ring. Small effects on lipolysis in vitro are obtained at concentrations of $5 \times 10^{-8} \mathrm{M}$, and maximum activity is reached at a concentration of $10^{-6}$ M. Even more active are the naturally occuring prostaglandins in the concentration range of $5 \times 10^{-9}$ to $10^{-7} \mathrm{M}[35,3]$. Their biologic half-life is very short. Many nucleosides and nucleotides inhibit lipolysis, but they are relatively less active than the drugs mentioned above $[9,25] . \alpha$ - and $\beta$-receptor blocking agents are not listed in this table.
Effects of 5-methylpyrazole-3-carboxylic acid and prostaglandine $E_{1}$ on adipose tissue metabolism in vitro and comparison with those of insulin

The main effects of 5-methylpyrazole-3-carboxylic acid and of prostaglandin $\mathbf{E}_{1}$ on adipose tissue of normal fed rats are shown in Fig. 7. Both drugs increase glucose incorporation into total lipids, $\mathrm{CO}_{2}$ and

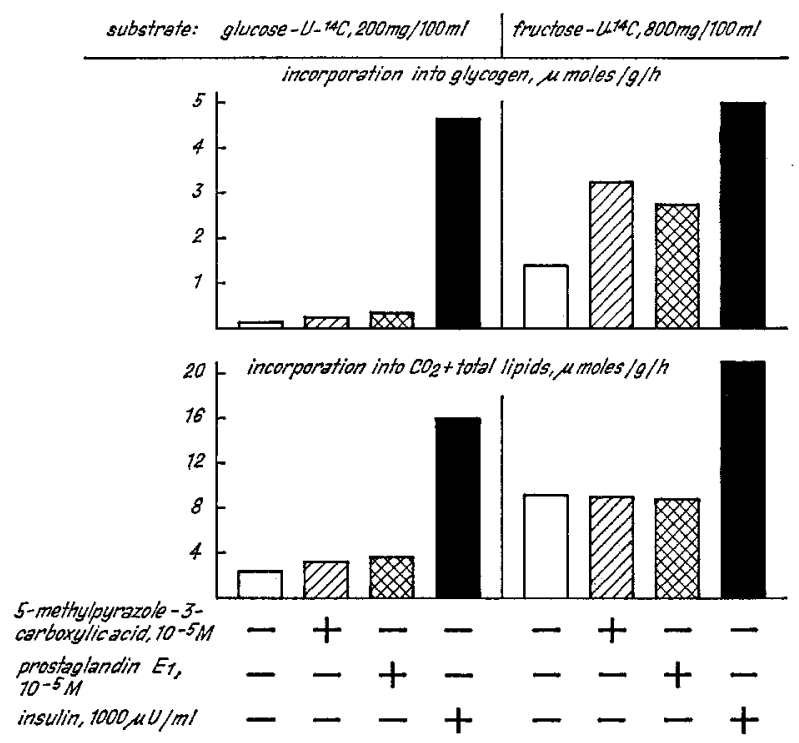

Fig. 7. Comparison of the effects of 5-methylpyrazole-3carboxylic acid, prostaglandin $\mathrm{E}_{1}$ and of insulin on glucose-U. ${ }^{14} \mathrm{C}$ - and fructose-U. ${ }^{14} \mathrm{C}-$ metabolism of pooled epididymal adipose tissue of normal, fed rats in vitro

The bars give the mean of the results of two flasks

glycogen. Insulin is much more effective. Under insulin stimulation incorporation of glucose-U. ${ }^{14} \mathrm{C}$ into glycogen accounts for approximately $25 \%$ of total glucose metabolism. 5-methylpyrazole-3-carboxylic acid and prostaglandin do not affect the incorporation of fructose-U- ${ }^{19} \mathrm{C}$ into $\mathrm{CO}_{2}$ and total lipids, while they approximately double its incorporation into glycogen. The same phenomenon is also seen when the metabolism of adipose tissue of fasted-refed rats is studied (Fig. 8). Both drugs reduce the glycerol release of adipose tissue of fasted-refed rats to approximately $15 \%$ of the base line. They stimulate glucose metabolism and incorporation of glucose-U-I4 $\mathrm{C}$ into glycogen to a small extent. Fructose- $\mathrm{U}_{-}{ }^{14} \mathrm{C}$ incorporation into total lipids and $\mathrm{CO}_{2}$ is not stimulated, whereas its incorporation into glycogen is increased manyfold.

These data favour the concept that fructose enters the adipose tissue cell, and that it is converted to glucose-6-phosphate in a compartment which is particularly favourable for glycogen synthesis [17]. In contrast, insulin apparently leads to formation of glucose-6-phosphate in a compartment in which glycogen synthesis takes place only at very high rates of glucose-6-phosphate formation. 
On the basis of the results of BUTCHER et al. [5] and of Jungas [22] one may draw the following purely hypothetical scheme (Fig. 9) of the regulation of lipolysis and of glycogen metabolism by lipolytic

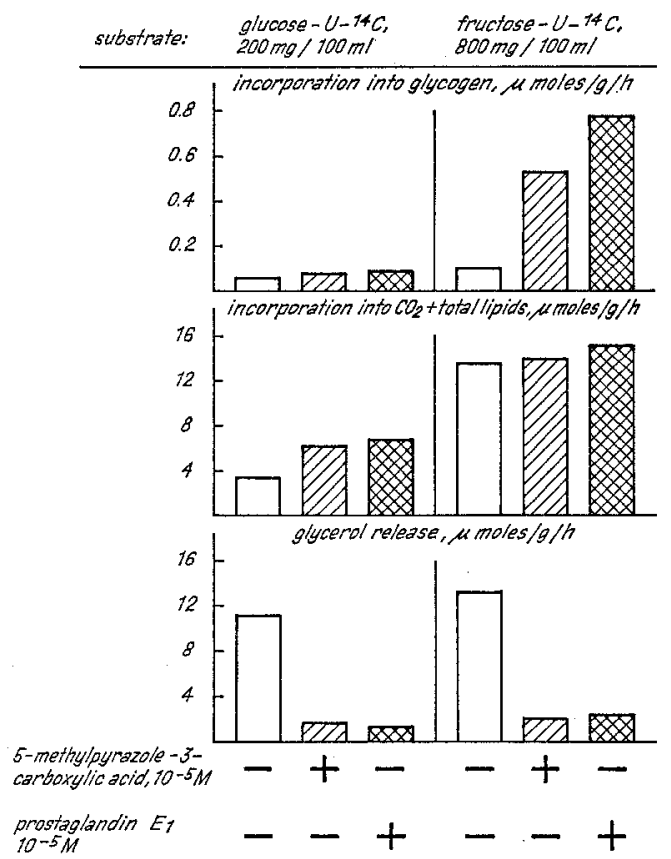

Fig. 8. Effects of 5-methylpyrazole-3-carboxylic acid and of prostaglandin $\mathrm{E}_{1}$ on glycerol release, glucose-U- ${ }^{14} \mathrm{C}$ and fructose-U-U ${ }^{14} \mathrm{C}$-metabolism of adipose tissue of fasted - refed rats

The bars give the mean of the results of two flasks
Butcher and StTherLand [6]). Lipolytic hormones activate adenyl-cyclase, and theophylline inhibits phospho-di-esterase, thus increasing the intracellular concentration of eyclic $3^{\prime} 5^{\prime}$-AMP. Insulin and other antilipolytic drugs appear to inhibit the stimulatory effects of lipolytic hormones on adenyl-cyclase, thereby keeping the concentration of cyclic $3^{\prime} 5^{\prime}$-AMP low. Whereas the induction of lipolysis by lipolytic hormones is counteracted by propranolol, lipolysis of adipose tissue of fasted-refed rats does not appear to depend on the activation of the $\beta$-receptors. Therefore, it is not yet certain whether or not cyclic $3^{\prime} 5^{\prime}$-AMP plays the same crucial role in the regulation of lipolysis and glycogen metabolism of adipose tissue of fastedrefed rats as it may play in the stimulation of lipolysis by lipolytic hormones and theophylline.

\section{Effects of antilipolytic drugs on the metabolism of adipose tissue in vivo}

We have tested the antilipolytic effects of 3 methylpyrazole-3-carboxylic acid in rats in vivo, and were struck by the marked insulin-like effects which this drug exerts on glucose metabolism of adipose tissue in vivo. 5-methylpyrazole-3-carboxylic acid stimulates the incorporation of ${ }^{14} \mathrm{C}$-labelled glucose into adipose tissue as markedly as a large dose of insulin, whereas it is without any effect on the incorporation of glucose into glycogen of the diaphragm.

The experiments, the results of which are shown in Fig. 10, were carried out in the following manner: $100 \mathrm{~g}$ rats were anaesthetized with a barbiturate, and subsequently injected intravenously with various doses of 5-methylpyrazole-3-carboxylic acid together with glucose $-{ }^{14} \mathrm{C}$ according to a method previously published $[18,16]$. The rats were decapitated 30 min later and the blood, diaphragm and epididymal fat pads were examined. As may be seen, $1.26 \mu \mathrm{g}$ of 5-methylpyrazole-3-carboxylic acid significantly lowers the free fatty acid level, and a maximal depression is obtained with doses of 126 to $1260 \mu \mathrm{g}$ per rat. The incorporation of labelled glucose into total lipids and fatty acids of adipose tissue is significantly stimulated by $12.6 \mu \mathrm{g}$ of the drug per rat.

Fig. 9. Reactions involved in the regulation of the level of cyclic $3^{\prime}, 5^{\prime}$-AMP in adipose tissue and the influence of cyclic $3^{\prime}, 5^{\prime}$-AMP on the rate of lipolysis and on glycogen metabolism

A causal relationship between the level of cyclic $3^{\prime}, 5^{\prime}$-AMP and the activity of these enzymes of adipose tissue has not yet been established. Levels of cyclic $3^{\prime}, 5^{\prime}$-AMP have not been reported for tissue of fasted - refed rats. This scheme is based on the experimental findings of BUTCHER et al. [5] and JUNGAS [22]

hormones and by their inhibitors. The metabolic reactions governing the rate of lipolysis, glycogen formation and glycolysis centre around cyclic $3^{\prime} 5^{\prime}$ AMP, the so-called second messenger of Sutherland. The formation of cyclic $3^{\prime} 5^{\prime}$-AMP is regulated by the activity of adenyl-cyclase and its degradation by the activity of phospho-di-esterase (for a review see
The time course of the effects of intravenously administered 5-methylpyrazole-3-carboxylic acid is demonstrated in Fig. 11. The level of free fatty acids is significantly depressed by 5-methylpyrazole-3carboxylic acid throughout the entire period of observation. Blood sugar and glucose assimilation are not affected by the drug despite its marked effects on 
glucose assimilation by adipose tissue. This and the following experiments demonstrate that the importance of adipose tissue with regard to overall glucose assimilation has been grossly overestimated because of its avidity for glucose in vitro. Incorporation of glucose-6- ${ }^{14} \mathrm{C}$ into glycogen of diaphragm is not increased by 5-methylpyrazole-3-carboxylic acid.

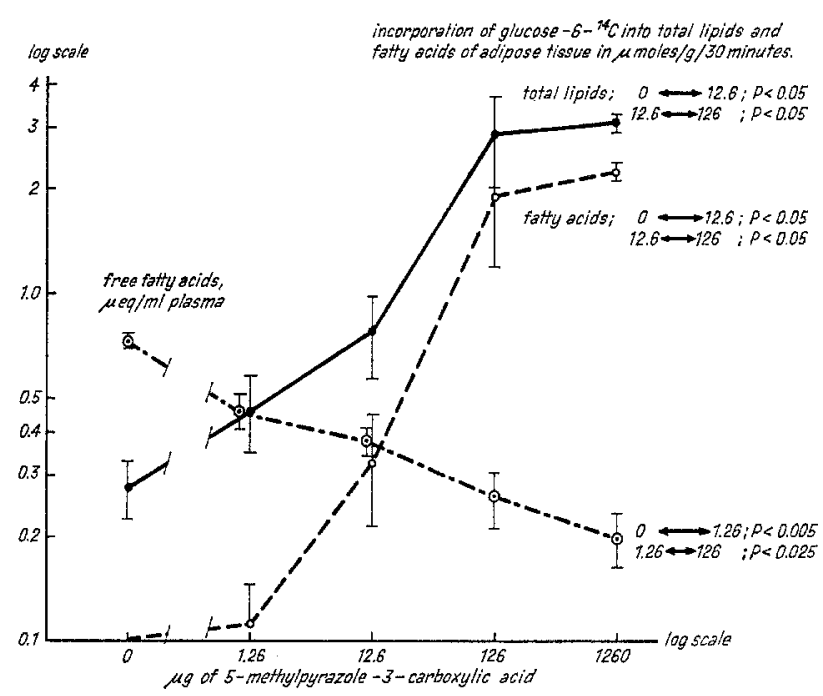

Fig. 10. Effects of 4 doses of intravenously administered 5-methyl-pyrazole-3-carboxylic acid on plasma free fatty acids and on the incorporation of glucose- $6-{ }^{14} \mathrm{C}$ into total lipids and fatty acids of adipose tissue

5-Methylpyrazole-3-carboxylic acid was dissolved in physiologic saline and $1 \mathrm{ml}$ was administered intravenously together with a tracer dose of glucose-6 ${ }^{14} \mathrm{C}$. The rats were killed after $30 \mathrm{~min}$. The means of the results of 4 rats and the SEM are given. The specific activity of the blood glucose at the time of sacrifice was used to express the results of the incorporation into adipose tissue in terms of $\mu$ moles glucose $-6 .{ }^{14} \mathrm{C}$ per $\mathrm{g}$ per $30 \mathrm{~min}$. (From Frowsch et al. [18])

Experiments of the same type were carried out with nicotinic acid and with prostaglandin, i.e. drugs of comparable structure, or of different structure but with similar antilipolytic potency. Table 4 shows that nicotinic acid does not only depress the level of free fatty acids, but that it shares with 5-methylpyrazole-3carboxylic acid the stimulatory activity on glucose incorporation into total lipids and fatty acids of adipose tissue. Nicotinic acid does not stimulate glucose metabolism of the diaphragm. The results obtained with prostaglandin $\mathrm{E}_{1}$ are shown in Fig. 12. Again, glucose uptake of adipose tissue is stimulated, whereas incorporation of glucose-6- ${ }^{14} \mathrm{C}$ into glycogen of diaphragm is not.

Thus, we may conclude that all these drugs with antilipolytic activity share a marked glucose uptakepromoting activity in adipose tissue in vivo, a finding which was unexpected on the basis of the in vitro results, which had indicated only a very weak activity on glucose uptake and a marked antilipolytic activity.

\section{Studies on the antidiabetic properties of 5-methylpyrazole-} 3-carboxylic acid

As shown in Table 5, 5-methylpyrazole-3-carboxylic acid blocks the hyperglycaemic response to the intravenous injection of anti-insulin serum in rats. Whereas the free fatty acid level rises to $1.58 \mu \mathrm{eq} / \mathrm{ml}$

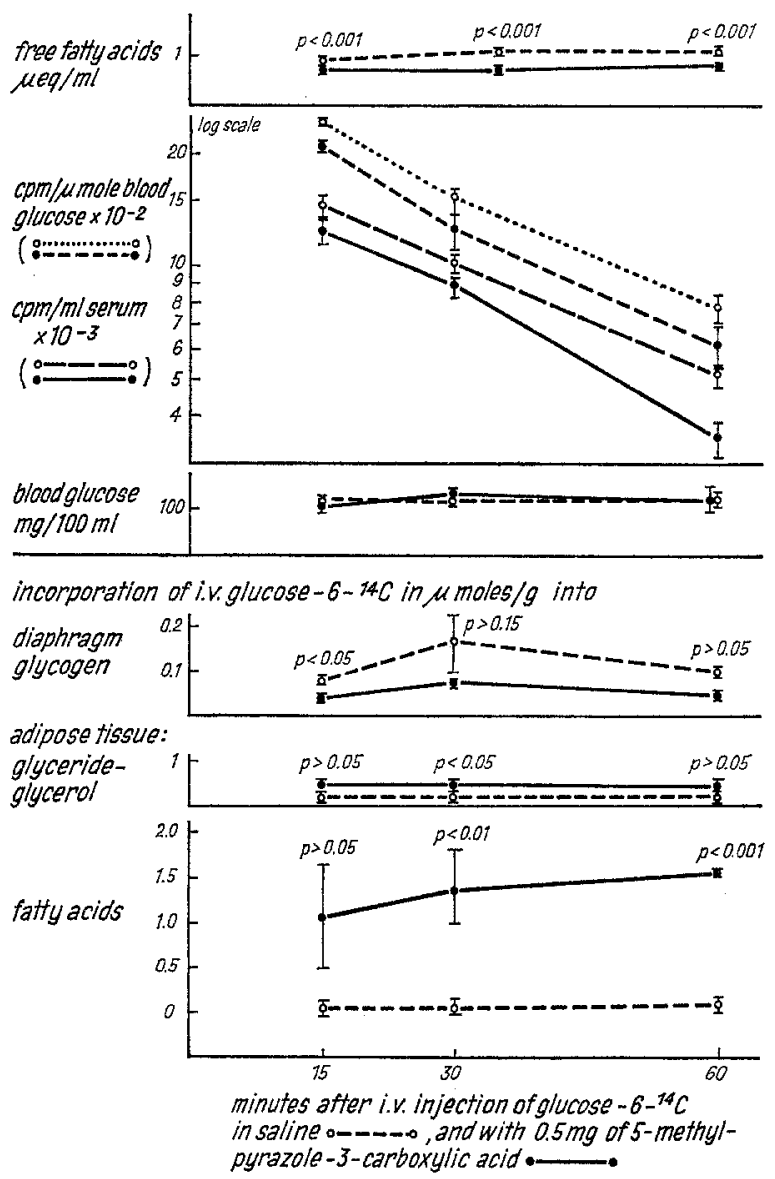

Fig. 11. Effects of intravenously administered 5-methylpyrazole-3-carboxylic acid on blood glucose, plasma free fatty acids and incorporation of glucose-6-14 $\mathrm{C}$ into tissues as a function of time

$0.5 \mathrm{mg}$ of 5 -methylpyrazole-3-carboxylic acid in $1 \mathrm{ml}$ saline was injected intravenously together with a tracer dose of glucose- $6{ }^{14} \mathrm{C}$. Control rats were given $1 \mathrm{ml}$ of saline. The rats were sacrificed after 15,30 and $60 \mathrm{~min}$, respectively. The means of the results of 4 rats and the SEM are given. The specific activity of the blood glucose at the half time between injection and sacrifice was used to express the results in terms of $\mu$ moles of glucose- $6-{ }^{14} \mathrm{C}$ incorporated per g. (From Frowsch et al. [18])

plasma in the rats treated with anti-insulin serum alone, it stays at the initial level of $0.98 \mu \mathrm{eq} / \mathrm{ml}$ in the rats which, in addition to anti-insulin serum, received $1 \mathrm{mg}$ of the pyrazole derivative.

In the experiment, the results of which are shown in Fig. 13, the antidiabetic activity of the pyrazole is further analyzed. 5-methylpyrazole-3-carboxylic acid stimulates the incorporation of glucose- $-{ }^{-14} \mathrm{C}$ into total 
lipids of adipose tissue in the presence of anti-insulin serum as much as in its absence. Insulin is not a prerequisite for the effect of 5-methylpyrazole-3. carboxylic acid in adipose tissue in vivo. The drug does not increase the glycogen formation in muscle from by muscle in spite of the total lack of insulin. Thus, a lack of insulin does not necessarily lead to decreased glucose oxidation by muscle, provided that the level of free fatty acids is kept low. These results are in good agreement with data from experiments in vitro in which

Table 4. Effects of two doses of intravenously administered nicotinic acid on the level of free fatty acids and on the ineorporation of intravenously injected glucose-6 ${ }^{14} \mathrm{C}$ into total lipids and fatty acids of adipose tissue and into glycogen of the diaphragm

Nicotinic acid was dissolved in saline and $1 \mathrm{ml}$ was injected into the tail vein. The rats were killed after $30 \mathrm{~min}$. The means of the results obtained in 5 rats and the standard error of the means are given. Students t-test was applied for statistical analysis. The results, which are expressed as $\mu$ moles of glucose-6-14C incorporated per $g$ per $h$, were obtained by dividing the counts per min in the respective metabolic indices by the specific activity of the blood glucose at the time of sacrifice (From Frowsch et al. [18]).

$P^{*}=$ statistical analysis between control group receiving saline and the group receiving $1.2 \mathrm{mg}$ of nicotinic acid.

\begin{tabular}{|c|c|c|c|c|c|c|c|}
\hline \multirow{4}{*}{$\begin{array}{l}\text { i.v. admini- } \\
\text { stration of }\end{array}$} & \multicolumn{5}{|c|}{ incorporation of glucose-6- ${ }^{24} \mathrm{C}$ in $\mu$ moles $/ g / 30^{\prime}$ into } & \multirow{3}{*}{\multicolumn{2}{|c|}{$\begin{array}{l}\text { free fatty acids } \mu \mathrm{eq} / \mathrm{ml} \\
\text { plasma }\end{array}$}} \\
\hline & \multirow{2}{*}{\multicolumn{4}{|c|}{$\frac{\text { adipose tissue }}{\text { total lipids }}$}} & \multirow{3}{*}{$\begin{array}{l}\text { diaphragm } \\
\text { glycogen } \\
\text { mean } \pm \text { SEM }\end{array}$} & & \\
\hline & total lipids & & & & & & \\
\hline & mean \pm SEM & $p$ & mean \pm SEM & $p$ & & mean \pm SEML & $p$ \\
\hline \multirow{3}{*}{$\begin{array}{l}\mathrm{NaCl}, 9 \% \\
1 \mathrm{ml} \\
\text { nicotinic acid, } \\
0.12 \mathrm{mg} \\
\text { nicotinic acid, } \\
1.2 \mathrm{mg}\end{array}$} & $0.23 \pm 0.06$ & \multirow{3}{*}{$\begin{array}{l}<0.005 \\
>0.10\end{array}$} & $0.07 \pm 0.04$ & \multirow{3}{*}{$\begin{array}{l}<0.01 \\
>0.10\end{array}$} & \multirow{3}{*}{$\begin{aligned} 0.06 & \pm 0.01 \\
p & >0.25 \\
0.05 & \pm 0.01 \\
p & >0.10 \\
0.07 & \pm 0.01\end{aligned}$} & $0.73 * \pm 0.04$ & \multirow{3}{*}{$<* 0.0005$} \\
\hline & $3.07 \pm 0.68$ & & $2.13 \pm 0.58$ & & & $0.70 \pm 0.29$ & \\
\hline & $4.91+1.14$ & & $4.07 \pm 1.15$ & & & $0.28 * \pm 0.02$ & \\
\hline
\end{tabular}

Table 5. Effects of 5-methylpyrazole-3-carboxylic acid, insulin, anti-insulin serum alone and with 5-methylpyrazole-3-carboxylic acid on blood glucose and free fatty acids

$1 \mathrm{ml}$ of saline with $3 \mathrm{~g}$ albumin $/ 100 \mathrm{ml}$ or of undiluted dialyzed anti-insulin guinea-pig serum was injected into the tail vein with or without $0.5 \mathrm{mg}$ of 5 -methylpyrazole-3-carboxylic acid. The dose of insulin was $6 \mathrm{mU}$ per rat. The rats were killed 30 min after the intravenous injection. The means of the results obtained in 4 rats and the SEM are given (From Froesch et al. [18]).

\begin{tabular}{|c|c|c|c|c|c|}
\hline & \multicolumn{5}{|c|}{ administration $30 \mathrm{~min}$ prior to sacrifice of } \\
\hline & albumin & $\begin{array}{l}\text { albumin } \\
+t \\
\text { insulin }\end{array}$ & $\begin{array}{l}\text { albumin } \\
+ \\
5 \text {-methylpyrazole-3- } \\
\text { carboxylie acid }\end{array}$ & $\begin{array}{l}\text { anti-insulin } \\
\text { serum }\end{array}$ & $\begin{array}{l}\text { antit-insulin } \\
\text { serum + } \\
\text { 5-methylpyrazole- } \\
\text { 3-carboxylic acid }\end{array}$ \\
\hline $\begin{array}{l}\text { blood glucose } \\
\mathrm{mg} \%\end{array}$ & $139.6 \pm 3.8$ & $109.2 \pm 7.0$ & $126.0 \pm 5.6$ & $203.8 \pm 1.9$ & $145.6 \pm 3.4$ \\
\hline $\begin{array}{l}\mathrm{P} \text { versus } \\
\text { albumin }<\end{array}$ & & 0.01 & 0.10 & 0.005 & 0.20 \\
\hline $\begin{array}{l}\text { free fatty } \\
\quad \text { acids } \\
\mu \theta q / m l\end{array}$ & $1.262 \pm 0.012$ & $0.914 \pm 0.033$ & $1.066 \pm 0.012$ & $1.580 \pm 0.031$ & $0.980 \pm 0.020$ \\
\hline $\begin{array}{l}P \text { versus } \\
\text { albumin < }\end{array}$ & & 0.0005 & 0.0005 & 0.0005 & 0.0005 \\
\hline
\end{tabular}

glucose-6-14C. 5-methylpyrazole-3-carboxylic acid is devoid of a significant effect on total activity of serum glucose, i.e. it does not significantly increase glucose turnover despite its effects on glucose metabolism of adipose tissue. However, the block on the outflow of glucose into tissues due to anti-insulin serum is brought back to normal by 5-methylpyrazole-3-carboxylic acid. This can not be explained by its action on glucose uptake of adipose tissue since the same stimulation did not influence overall glucose turnover in the absence of anti-insulin serum. Rather, it is due to the anti-lipolytic action of this drug. By keeping the level of free fatty acids low, glucose is being oxidized muscle metabolized and oxidized free fatty acids at high concentrations in preference to glucose $[11,27,38$, 30]. Thus, 5-methylpyrazole-3-carboxylic acid prevents hyperglycaemia in acutely-induced insulin deficiency. These promising results in acutely diabetic rats have been extended to chronically diabetic rats, where 5-methylpyrazole-3-carboxylic acid also stimulates the glucose uptake of adipose tissue and lowers the level of free fatty acids (Frossch, unpublished data). However, when decompensation of carbohydrate and lipid metabolism due to insulin deficiency lasted for several days, overall glucose utilization was no longer normalized by a mere depression of the free fatty acid level. 
Escape from the acute antilipolytic effects of 5-methylpyrazole-3-carboxylic acid during prolonged administration of 5-methylpyrazole-3-carboxylic acid

It has been described that the inhibition of free fatty acid release in vivo by nicotinic acid may be followed by an overshooting lipolysis resulting in increased levels of free fatty acids [8, 28]. We have observed a similar phenomenon in rats treated for 5 days with 5-methylpyrazole-3-carboxylic acid [18]. The results of such an experiment are shown in Fig. 14.

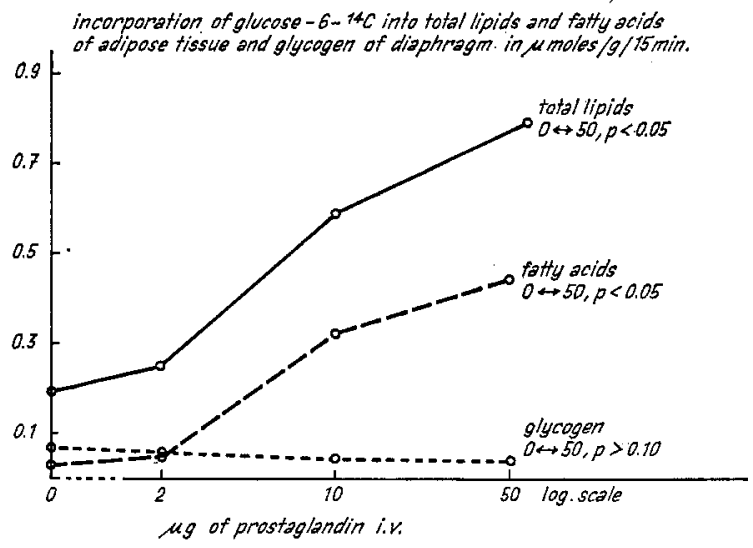

Fig. 12. Effects of intravenously administered prostaglandin $\mathrm{E}_{\mathbf{1}}$ on the incorporation of intravenously injected glucose $-6-{ }^{14} \mathrm{C}$ into total lipids and fatty acids of adipose tissue and glycogen of the diaphragm

Each dot gives the mean of the results obtained in 5 rats

The plasma level of free fatty acids is significantly higher in rats pretreated with 5-methylpyrazole-3carboxylic acid than in control rats, $5 \mathrm{~h}$ after the last subcutaneous injection. The acute depression of the plasma free fatty acids by the intravenously administered drug is the same in both groups of rats, but the subsequent behaviour of the free fatty acid level is very different. In the group pretreated with 5-methylpyrazole-3-carboxylic acid it rises rapidly to the initial levels, whereas it stays low in the control group during the whole period of observation. Stimulation of the incorporation of labelled glucose into fatty acids and glyceride-glycerol of adipose tissue is more marked acutely after the injection of 5-methylpyrazole-3carboxylic acid in the premedicated rats than in the control rats. However, the glycerides synthesized under the influence of this drug seem to be hydrolyzed and released by the tissue very rapidly after their synthesis. The ${ }^{14} \mathrm{C}$-activity in the free fatty acids of the plasma is significantly higher in the rats pretreated with the drug than in the control rats $60 \mathrm{~min}$ after the intravenous injection of 5-methylpyrazole-3-carboxylic acid. These data indicate that under the chronic administration of pyrazole derivatives, both synthesis of glycerides from glucose as well as hydrolysis of freshly synthesized glycerides, are activated to a marked degree. The net result of these two phenomena is an actual elevation of the free fatty acid concentration above the control level. The observations on the alterations of adipose tissue metabolism after prolonged treatment with 5-methylpyrazole-3-carboxylic acid are shown in a schematic and simplified way in Fig. 15. The acute effect of antilipolytic drugs consists in an inhibition of lipolysis and in an increased uptake of glucose and formation of glycerides. The newly

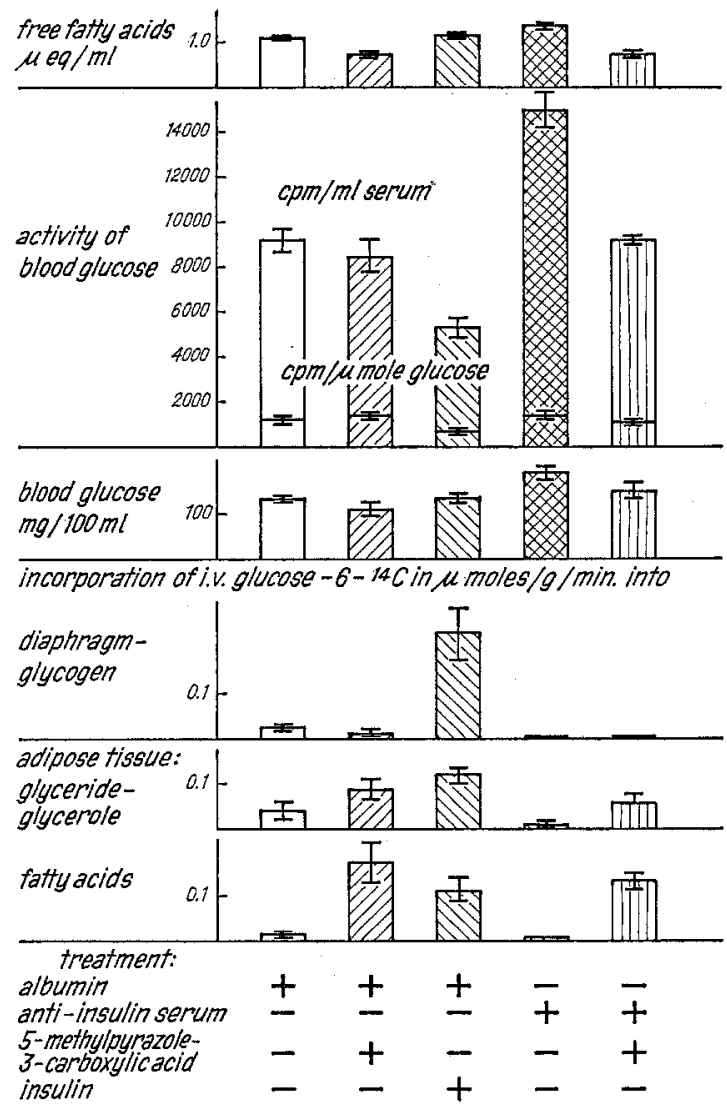

Fig. 13. Comparison of the effects of 5 -methylpyrazole-3. carboxylic acid with those of insulin on the metabolism of intravenously administered glucose-6-14 $\mathrm{C}$ in normal and acutely diabetic rats

Insulin deficiency was induced by the intravenous injection of $1 \mathrm{ml}$ of anti-insulin serum diluted $1: 2$. The dose of insulin was $6 \mathrm{mU}$ and that of 5-methylpyrazole-3carboxylic acid $1 \mathrm{mg}$ per rat. The means of the results obtained in 4 rats and the SEM are given. The specific activity of the blood glucose at the time of sacrifice was used to express the results of the incorporation in terms of glucose- $6-{ }^{14} \mathrm{C}$ per $\mathrm{g}$ per $30 \mathrm{~min}$

synthesized glycerides do not seem to mix readily with the main triglyceride depot. Somehow a lipase is induced, which splits the freshly synthesized glycerides as soon as the acute antilipolytic effect of the drug wears off. This general scheme also describes our observations on adipose tissue of fasted-refed rats. Maintenance of a high level of insulin over a prolonged. period of time induces a rise of basal lipase activity, which is nonfunctional in the presence of insulin. 
Conclusions and outlook on the prospectives for the treatment of diabetes

Randle's statement, which I put at the beginning of this lecture, that increased release and oxidation of free fatty acids is not necessarily the result of a deficient uptake and metabolism of glucose [29], has been amply illustrated by experiments in living rats

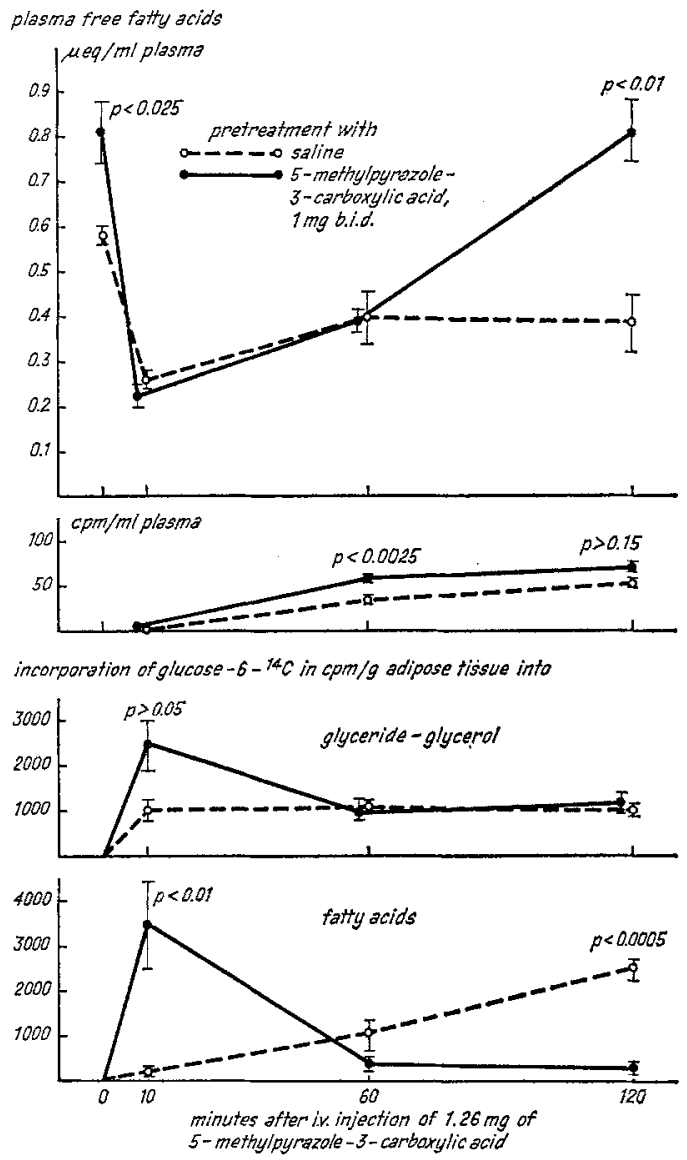

Fig. 14. Effects of 5-methylpyrazole-3-carboxylic acid on glucose metabolism and lipolysis of adipose tissue after pretreatment with this ldrug for 5 days

20 rats were injected subcutaneously with 1.26 $\mathrm{mg}$ of 5-methylpyrazole-3-carboxylic acid b.i.d. during 6 days. A control group received $1 \mathrm{ml}$ of sa. line b.i.d. $5 \mathrm{~h}$ after the last subcutaneous injection the rats were anesthetized and an intravenous dose of $1.26 \mathrm{mg}$ of 5-methylpyrazole-3-carboxylic acid was administered together with glucose $-6-{ }^{14} \mathrm{C}$. 5 rats of each group were killed after 10,60 and 120 min, respectively. The means of the results in 5 rats and the SEM are given. (From Froesch et al. [18])

[18]. Inhibition of free fatty acid release by 5-methylpyrazole-3-carboxylic acid blocks the hyperglycaemic response to acute insulin deficiency by keeping glucose oxidation by muscle normal. This concept may be broadened in such a way that increased glucose uptake by one tissue, i. e. adipose tissue, may eventually become responsible for increased lipolysis, free fatty acid release and oxidation.

From the point of view of therapy for diabetics antilipolytic drugs do not appear to be very promising [26]. They not only inhibit lipolysis, but they also markedly stimulate glucose uptake of adipose tissue. Treatment with antilipolytic drugs over prolonged periods of time would result in obesity, if adipose tissue did not develop mechanisms to get rid of the extra lipids synthesized from glucose. We have shown that an escape phenomenon occurs, and that chronic treatment with 5-methylpyrazole-3-carboxylic acid results in a rapid conversion of glucose to free fatty acids, and to an actual elevation of plasma free fatty acids above normal. We should expect that diabetics treated in this manner would become "brittle" and would tend to develop ketonuria.

Insulin also induces a lipase, but it suppresses its activity as long as it is present in blood. Thus, insulin may lead to an accumulation of fat as long as glucose is supplied and as long as the $\beta$-cells agree to secrete insulin.

In many diabetics before and after instalment of insulin therapy, phases of hyperinsulinism and of hypoinsulinism alternate due to the untimely secretion of endogenous, or the untimely administration of exogenous insulin. It may well be that lipolysis is activated by the above mentioned mechanism, resulting in difficulties in the stabilization of the metabolic situation. It is still one of the main tasks for every physician to try to find the right moment in every diabetic for the administration of the right kind of insulin.

Since antilipolytic activity is always associated with glucose uptake-promoting activity into adipose

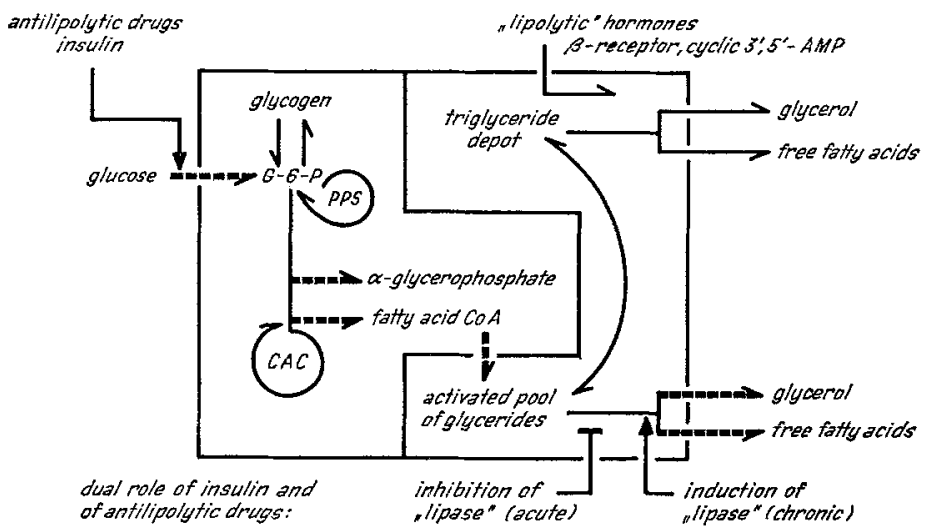

Fig. 15. Alterations of adipose tissue metabolism during prolonged treatment with 5-methylpyrazole-3-carboxylic acid and in the fasted-refed rats

Triglyceride synthesis from glucose is increased and their hydrolysis inhibited in the presence of antilipolytic substances. As soon as their action wears off, hydrolysis of the newly synthesized triglycerides, which do not seem to mix readily with the depot triglycerides, takes off at a rapid rate. Thus, glucose is rapidly converted to free fatty acids and a glucose to fatty acid shunt is established in adipose tissue. (From Froesch et al. [18]) 
tissue, leading to increased lipolysis, we may have to go back to drugs with truly insulin-like activity, i.e. to substances which stimulate the glucose metabolism of muscle as much or more so than that of adipose tissue. Purified nonsuppressible ILA may well fulfill this requirement. It is a peptide with a molecular weight of approximately 6000 , which may be extracted from serum and which mimicks most of the effects of insulin $[16,4,14]$. As shown in Fig. 16, this substance is more

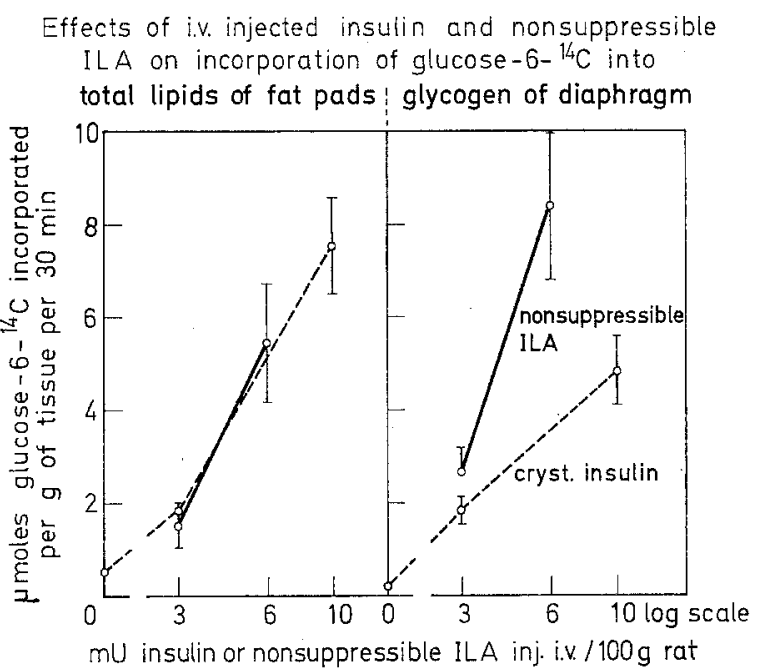

Fig. 16. Effects of intravenously administered insulin and purified nonsuppressible ILA on the incorporation of glucose- $6-{ }^{14} \mathrm{C}$ into the total lipids of the fat pad and the glycogen of the diaphragm

In these experiments the specific activity of the serum glucose at the time of sacrifice was used for calculation of the $\mu$ moles of glucose- $6{ }^{-14} \mathrm{C}$ which were incorporated into the glycogen and total lipids. The number of rats was 20 in all but those groups of rats injected with 3 and $6 \mathrm{mU}$ nonsuppressible ILA in which it was 4 . The bars indicate the S.E. The effect of $6 \mathrm{mU}$ nonsuppressible ILA on the incorporation of glucose- $6{ }^{14} \mathrm{C}$ into glycogen was significantly greater than that of $10 \mathrm{mU}$ crystalline insulin $(P<0.05)$

$\mathrm{O}-\mathrm{O}$, crystalline insulin; - nonsuppressible ILA. (From Frowsch et al. [16])

active on the diaphragm than on adipose tissue compared with insulin. We are now further purifying this molecule and hope to get enough material to test it in man for favourable anti-diabetic properties.

Acknowledgements. I should like to express my deeply felt gratitude to Professors A.E. REnOLD and A. LABHART, who have introduced me in their comprehensive, progressive and seducing way into experimental medicine, endocrinology, and into the art of teamwork, and for their continued interest and encouragement of our efforts in the laboratory. I have always enjoyed the sometimes rather harsh but extremely helpful criticism of Dr. R. E. Humber and Dr. J. Müller. The work presented today is the result of a collaborative effort of many friends who oracefully bore the hardship of all the negative personal characteristics that make oneself elligible for a prize. My particular thanks go to Drs. H. BüRGI, A. JAKoB, U.A. Meyer, W.A. MÜLler, J.L. Ginsberg and
E. Ramseter and to Misses M. Watdvoger, V. SturzenEGGER, S. DIEM and Ch. ÁmaRk. They all have kept the banner of our metabolic unit high in good and bad times. I deplore my wife's and my children's bad luck of having to bear a stubborn scientist as a husband and father. However, I am quite sure that my wife is just as happy as I am that the Minkowski prize will keep us from starving for another year. I wish to thank the European Association for the Study of Diabetes and Hoechst AG for having chosen me as this year's recipient. Finally, I should like to acknowledge the financial support of the Schweizerische Nationalfonds and of the US Public Health Service, which made the realization of these studies possible.

\section{References}

[1] Bally, P.R., H. Kappeler, E.R. Frofsch and A. LABHART: Effects of ghcose on spontaneous limitation of lipolysis in isolated adipose tissue: a potential regulatory mechanism. Ann. N.Y. Acad. Sci. 131, $143-156(1965)$.

[2] BLECHER, M.: Tffects of insulin and phospholipase on glucose transportation across the plasma membrane of free adipose cells. Biochim. biophys. Acta $137,557-571(1967)$.

[3] Böhre, E., E. Döbert, J. Ammann and H. DitSCHUNETT: Über Stoffwechselwirkungen von Prostaglandinen. I. Der Einfluß von Prostaglandin E auf den Glucose- und Fettstoffwechsel des epididymalen Fettgewebes der Ratte. Diabetologia 2, $162-$ $168(1966)$.

[4] BÜrgi, H., W.A. MÜLler, R.E. Humbet, A. LABhart and E.R. Fromsch: Nonsuppressible insulinlike activity of human serum. I. Physicochemical properties, extraction and partial purification. Biochim. biophys. Acta 121, 349-359 (1966).

[5] Butomer, R.W., R.J. Ho, H.C. Meng and E.W. SUTHerlasd: Adenosine $3^{\prime}, 5^{\prime}$-monophosphate in biological material. II. The measurement of adenosine $3^{\prime}, 5$-monophosphate in tissues and the role of the cyclic nucleotide in the lipolytic response of fat to epinephrine. J. biol. Chem. 240, 4515-4523 (1965).

$[6]$-, and E.W. Sutherland: The effects of the catecholamines, adrenergic blocking agents, prostaglandin $E$ and insulin on eyclic $3^{\prime}, 5^{\prime}$-AMP levels in the rat epididymal fat pad in vitro. Ann. N.Y. Acad. Sci. 139, 849-859 (1967).

[7] CARLsoN, L.A., and P.R. BaLIY: Inhibition of lipid mobilization. In: A.E. ReNord and G.F. CAHILL (Eds.), Handbook of Physiology, Section 5, Adipose tissue, p. 557-574. Washington, D.C.: American Physiological Society 1965.

[8] - , and J. OESTMAN : Inhibition of the mobilization of free fatty acids from adipose tissue in diabetes. II. Effect of nicotinic acid and acetylsalicylate on blood glucose in human diabetics. Acta med. scand. 178, $71-79(1965)$.

[9] Dore, V.P.: Effect of nucleic acid metabolites on lipolysis in adipose tissue. J. biol. Chem. 236, 3125$3130(1961)$.

[10] Fais, J.W., V.P. Kovacev and R.O. Scow: Effects of growth hormone and dexamethasone on lipolysis and metabolism in isolated fat cells of the rat. J. biol. Chem. 240, 3522-3529 (1965).

[11] Frrtz, I.B.: Effects of insulin on glucose and palmitate metabolism by resting and stimulated rat diaphragm. Amer. J. Physiol. 198, 807-810 (1960).

[12] Frofsch, E.R.: Essential Fructosuria and Hereditary Fructose Intolerance. In: Stanbury, FredRICKSON and WyNGAARDEN (Eds.), The Metabolic Basis of Inherited Disease, p. 124-140. Now York: MeGraw Hill Inc. 1965. 
[13] -., H. BüRgI, P. BAtLY and A. LAB.HART: Insulin inhibition of spontaneous adipose tissue lipolysis and effects upon fructose and glucose metabolism. Mol. Pharmacol. 1, 280-296 (1965).

[14] - W.A. Müller, R. E. Humbet, A. Jakob and A. LabHaRT: Nonsuppressible insulin-like activity of human serum: Purification, physicochemical and biological properties and its relation to total serum ILA. Recent Progr. Hormone Res. 23, 565-605 (1967).

[15] -, and J.L. Ginsberg: Fructose Metabolism of Adipose Tissue. I. Comparison of fructose and glucose metabolism in epididymal adipose tissue of normal rats. J. biol. Chem. 237, 3317-3324 (1962).

[16] - W.A. Mülrer, H. Bürgr, M. W ALdVoget and A. LABHaRt: Nonsuppressible insulin-like activity of human serum. II. Biological properties of plasma extracts with nonsuppressible insulinlike activity. Biochim. biophys. Acta 121, 360-374 (1966).

[17] - M. Waldvogel, U.A. Meyer, A. Jakob and A. LABHART: Effects of 5-methylpyrazole-3-carboxylic acid on adipose tissue. I. Inhibition of lipolysis, effects on glucose-, fructose- and glycogen-metabolism in vitro and comparison with insulin. Mol. Pharmacol. 3, 429-441 (1967).

[18] - - - - Effects of 5-methylpyrazole-3-car boxylic acid on adipose tissue. II. Antilipolytic and hypoglycemic effects in vivo. Mol. Pharmacol. 3, $442-452(1967)$

[19] Gerritsen, G.C., and W.E. Dulin: The effect of 5-methylpyrazole-3-carboxylic acid on carbohydrate and free fatty acid metabolism. J. Pharmacol exp. Ther. 150, 491-498 (1965).

[20] Hales, C.N., and P.J. Rander: Effects of low carbohydrate diet and diabetes mellitus on plasma concentrations of glucose, non-esterified fatty acids and insulin during oral glucose tolerance tests. Lancet 1963 I, 790-793.

[21] Hepp, D., Ph. L. Poffenderger, J.W. Ensinck and R.H. WILLIAMs : Effects of nonsuppressible insulinlike activity and insulin on glucose oxidation and lipolysis in the isolated adipose tissue cell. Metabolism 16, 393-401 (1967).

[22] Jungas, R.L.: Role of cyclic $3^{\prime}, 5^{\prime}$-AMP in the response of adipose tissue to insulin. Proc. nat. Acad. Sci. 56, 757-763 (1966).

[23] - and E.G. BALL: Studies on the metabolism of adipose tissue. XII. The effects of insulin and epinephrine on free fatty acid and glycerol production in the presence and absence of glucose. Biochemistry 2, 383-388 (1963).

[24] - - Studies on the metabolism of adipose tissue. XVII. In vitro effects of insulin upon the metabolism of the carbohydrate and triglyceride stores of adipose tissue from fasted-refed rats. Biochemistry 3 , $1696-1702$ (1964).

[25] KAPPELER, H.: Zur Pharmakologie der Lipolysehemmung. I. Wirkungsweise adenosinhaltiger Nucleoside und Nucleotide auf die Lipolyse des Fottgewebes in vitro. Diabetologia 2, 52-61 (1966).

[26] Molnar, G.D., K. G. Borge, J.W. Rosevater, W.F. MCGUCKIN and R.W.P. ACHOR: The effect of nico- tinic acid in diabetes mellitus. Metabolism $\mathbf{1 3}$, $181-190(1964)$.

[27] OpIE, L.H., J.R. Evans and J.C. Shipp: Effect of fasting on glucose and palmitate metabolism of perfused rat heart. Amer. J. Physiol. 205, 12031208 (1963).

[28] Pinter, E.J., and C.J. Pattee; Biphasic nature of blood glucose and free fatty acid changes following intravenous nicotinic acid in man. J. clin. Endocr. 27, $440-443$ (1967).

[29] RANDLE, P.J.: Carbohydrate metabolism and lipid storage and breakdown in diabetes. Diabetologia $\mathbf{2}$, $237-247(1.966)$.

[30] - E.A. Newshoume and P.B. Gartand: Regulation of glucose uptake by muscle. 8. Effects of fatty acids, ketone bodies and pyruvate, and diabetes and starvation on uptake and metabolic fate of glucose in rat heart and diaphragm muscle. Biochem. J.93, $652-664$ (1964).

[31] Robinson, D.S.: The clearing factor lipase activity of adipose tissue. In: A.E. RENOLD and G.F. CA. HILl, Jr., (Eds.), Handbook of Physiology, Section 5, Adipose tissue, p. 295-299. Washington, D.C.: American Physiological Society 1965.

[32] Ropberi, M., and A.B. Jones: Metabolism of isolated fat cells. III. The similar inhibitory action of phospholipase $\mathrm{C}$ (clostridium porfringens a toxin) and of insulin on lipolysis stimulated by lipolytic hormones and theophilline. J. biol. Chem. 241, 140 $142(1965)$.

[33] SMITH, D.L., A.A. Forist and W.E. DULiN: 5methylpyrazole-3-carboxylic acid. The potent hypoglycemic metabolite of 3,5-dimethylpyrazole in the rat. J. med. Chem. 8, 350-353 (1965).

[34] - J.G. WAGNER and G.C. GERRITSEN : Absorption, metabolism and excretion of 5-methylpyrazole-3-carboxylic acid in the rat, dog and human. J. Pharmocol. Sci., in press.

[35] Steinberg, D.M., M. Vaughan, P.J. Nester, O. Straud and S. BERGström: Effects of the prostaglandins on hormone induced mobilization of free fatty acids. J. clin. Invest. 43, $1533-1540$ (1964).

[36] Tarrant, M.E., R. Mahler and J. As amore: Studies in experimental diabetes. IV. Free fatty acid mobilization. J. biol. Chem. 239, $1714-1719$ (1964).

[37] VaUghar, M., and D. Steinberg: Glyceride biosynthesis, glyceride breakdown and glycogen breakdown in adipose tissue: Mechanism and regulation. In: "Handbook of Physiology" (A. E. Reroud and G.F. CAHILL, Jr. eds.), Section 5, Adipose tissue, p. 239-251. Washington, D.C.: American Physiological Society 1965.

[38] WILLIAMson, J.R.: Glycolytic control mechanisms. I. Inhibition of glycolysis by acetate and pyruvate in the isolated, perfused rat heart. J. biol. Chem. 240, 2308-2321 (1965).

Dr. E. R. Froesch

Metabolic Unit Department of Medicine

University of Zürich

CH-8006 Zürich, Switzerland 